\title{
Elaboration and Characterization of Active Apple Starch Films Incorporated with Ellagic Acid
}

\author{
Juan Manuel Tirado-Gallegos ${ }^{1}$, Paul Baruk Zamudio-Flores ${ }^{1, *}$, José de Jesús Ornelas-Paz ${ }^{1}$, \\ Claudio Rios-Velasco ${ }^{1}$, Guadalupe Isela Olivas Orozco ${ }^{1}$, Miguel Espino-Díaz ${ }^{1}$, \\ Ramiro Baeza-Jiménez ${ }^{2}$, José Juan Buenrostro-Figueroa ${ }^{2}$, Miguel Angel Aguilar-González ${ }^{3}$, \\ Daniel Lardizábal-Gutiérrez ${ }^{4}$, María Hernández-González ${ }^{5}$, Francisco Hernández-Centeno ${ }^{5}$ \\ and Haydee Yajaira López-De la Peña ${ }^{5}$
}

1 Coordinación de Tecnología de Alimentos de la Zona Templada, Centro de Investigación en Alimentación y Desarrollo, A.C., Avenida Río Conchos s/n, Parque Industrial, Cd. Cuauhtémoc, Chihuahua 31570, Mexico; jmtiradoga@gmail.com (J.M.T.-G.); jornelas@ciad.mx (J.d.J.O.-P.); claudio.rios@ciad.mx (C.R.-V.); golivas@ciad.mx (G.I.O.O.); aster3000@hotmail.com (M.E.-D.)

2 Centro de Investigación en Alimentación y Desarrollo, A.C., Unidad Delicias, Av. Cuarta Sur 3820, Fraccionamiento Vencederos del Desierto, Cd. Delicias, Chihuahua 33809, Mexico; ramiro.baeza@ciad.mx (R.B.-J.); jose.buenrostro@ciad.mx (J.J.B.-F.)

3 Centro de Investigación y de Estudios Avanzados del Instituto Politécnico Nacional, Unidad Saltillo, Av. Industria Metalúrgica 1062, Ramos Arizpe, Coahuila 25900, Mexico; mgzlz@hotmail.com

4 Laboratorio Nacional de Nanotecnología, Centro de Investigación en Materiales Avanzados, Miguel de Cervantes 120, Chihuahua, Chihuahua 31109, Mexico; pauba99@yahoo.com

5 Departamento de Ciencia y Tecnología de Alimentos, División de Ciencia Animal, Universidad Autónoma Agraria Antonio Narro, Calzada Antonio Narro 1923, Buenavista, Saltillo, Coahuila 2315, Mexico; maryhg12@yahoo.com (M.H.-G.); francisco.hdezc@gmail.com (F.H.-C.); Yajaira.lp@gmail.com (H.Y.L.-D.1.P.)

* Correspondence: pzamudio@ciad.mx; Tel.: +52-625-581-2920 (ext. 111)

Received: 18 September 2018; Accepted: 23 October 2018; Published: 27 October 2018

\begin{abstract}
Apple starch films were obtained from apples harvested at 60, 70, 80 and 90 days after full bloom (DAFB). Mechanical properties and water vapor permeability (WVP) were evaluated. The apple starch films at 70 DAFB presented higher values in the variables of tensile strength $(8.12 \mathrm{MPa})$, elastic modulus $(3.10 \mathrm{MPa})$ and lower values of water vapor permeability $\left(6.77 \times 10^{-11} \mathrm{~g} \mathrm{~m}^{-1} \mathrm{~s}^{-1} \mathrm{~Pa}^{-1}\right)$ than apple starch films from apples harvested at 60, 80 and 90 DAFB. Therefore, these films were chosen to continue the study incorporating ellagic acid (EA). The EA was added at three concentrations [0.02\% (FILM-EA0.02\%), 0.05\% (FILM-EA0.05\%) and 0.1\% (FILM-EA0.1\%) $w / w$ ] and compared with the apple starch films without EA (FILM-Control). The films were characterized by their physicochemical, optical, morphological and mechanical properties. Their thermal stability and antioxidant capacity were also evaluated. The FILM-Control and FILM-EA0.02\% showed a uniform surface, while FILM-EA0.05\% and FILM-EA0.1\% showed a rough surface and insoluble EA particles. Compared to FILM-Control, EA modified the values of tensile strength, elasticity modulus and elongation at break. The antioxidant capacity increased as EA concentration did. EA incorporation allowed obtaining films with higher antioxidant capacity, capable of blocking UV light with better mechanical properties than film without EA.
\end{abstract}

Keywords: active films; thermogravimetric analysis; UV protection; X-ray diffraction

\section{Introduction}

Plastics are synthetic polymers derived from fossil fuels, which because of its production cost and versatility are one of the most popular food packaging materials [1,2]. Despite that, the non-biodegradable 
nature of these materials has generated serious pollution problems [3]. For these reasons, the interest on developing edible films and coating that can totally or partially replace the use of synthetic polymers derived from petroleum, has grown [4,5]. Edible films can be obtained from proteins, carbohydrates, glycoproteins, lipids or their mixtures [6,7]. One of the most widely used natural biopolymers with a great potential in the production of biodegradable materials is starch [1,8]. Starch is the main energy reserve of higher plants, a natural resource, renewable, abundant and low cost [4]. Starch films offer several advantages for use as food packaging, being colorless, odorless, tasteless, transparent, biodegradable, non-toxic and with low oxygen permeability [9]. On the other hand, compared with synthetic polymers, starch films are highly hydrophilic with poor mechanical properties [3,4]. It has been reported that the different properties of starch-based films vary with the botanical source [10-15]. These variations are mainly due to the amylose content in the native starches $(18 \%-30 \%)$ [16]. The food industry is constantly looking for new sources of starches that may offer different or better functional properties [1,17]. Regarding to this, Stevenson et al. [18] evaluated the functional properties of starches isolated from immature apples of six cultivars, their results indicated that the amylose content was $26.0 \%$ to $29.3 \%$. In this sense, apple starches may form films with acceptable properties (due to its amylose content) and comparable to those obtained from conventional sources such as corn and wheat. Apple is a climacteric fruit, whose ripening process is regulated by ethylene [19]. Within its growth and development, the fruit is characterized by significant concentrations of starch, which become almost zero at the time of commercial harvest $[18,19]$. One of the most common practices in apple orchards is the fruit thinning. The objective of this process is to achieve the development of high-quality fruits with regular yields and high blooming return [20,21]. Besides, it is important to mention that in order to obtain a good commercial quality harvest, it is required that only between $5 \%$ and $30 \%$ of the flowers end up as mature fruits [22]. When fruit thinning in apple orchards is done manually (hand-thinning), it is recommended to do it at 28 DAFB. However, late manual thinning (60 DAFB) is a common practice in the region [20], which may be extended up to 70 DAFB. Although its benefits are well known, this practice is usually delay due to the farmers fear, that the damages by frost in orchard whose fruits has been previously thinned, diminish the harvest yield. Apples removed during the fruit thinning are considered as a waste and in the best case, they are used as animal feed or as compost [21]. An alternative for the use of the fruits eliminated by this practice may be the isolation of their starch for the development of biodegradable films. The packaging plays an important role in the food industry, it must to contain and protect the food against external and internal factors. Biodegradable films can control the mass exchange between the food and the surrounding medium increasing the extension of shelf life and improving the quality of foods [23,24]. There is increasing interest in developing biodegradable packaging that can be used as active packaging [25]. According to these, starch-based films can develop activities as carriers and active substances-releasing agents (antioxidants, antimicrobials, flavorings, among others) in to the food matrix by diffusion process, which gives rise to the active films [26,27]. At present, there has been an increasing interest in incorporating antioxidants in starch-based films, mainly plants extracts, which are often characterized by their content of phenolic compounds $[1,10,25,28,29]$. Ellagic acid (EA) is a phenolic compound found in a wide variety of vegetables, usually in the form of ellagitannins (its precursors). EA is mainly found in fruits such as pomegranates, raspberries and blueberries [30], it shows antimicrobial and anticancer properties, besides inhibiting the formation and growth of tumors in animals [31]. Definitely, one of its most studied properties is its ability to capture free radicals [31-33], due to its high antioxidant capacity, since it is a stable molecule at high temperatures, which melting point is $\sim 362{ }^{\circ} \mathrm{C}$ [34]. EA has previously been used to deal with melanoma cells in chitosan based-films, presenting anticancer activity at concentrations as low as $0.1 \%(w / v)$ [30]. It has also been applied on candelilla wax based coatings at a concentration of $0.01 \%(w / v)$ to minimize the changes of color and improve the texture of fresh-cut fruits [35] and to lengthen shelf life in avocados [36]. For all these reasons, it can be mentioned that the EA is a substance with varied biological activity, which has already been added to films for medical purposes; however, currently there are no reports on 
the incorporation on the properties of film formation in apple starches. The objective of this study consisted in evaluating the effect of incorporating EA, on the physicochemical, mechanical, thermal and antioxidant properties of apple starch-based films.

\section{Materials and Methods}

\subsection{Sample and Reagents}

Starch was obtained from Golden Delicious Smothee apples harvested at 60, 70, 80 and 90 days after full bloom (DAFB) during the production cycle of 2013 in the orchard "La Campana" at Ciudad Cuauhtemoc, Chihuahua, Mexico. Starch extraction was performed by wet milling according to the method reported by Tirado-Gallegos et al. [17].

\subsection{Preparation of Coating Solutions and Films}

Coating solutions and films were made with the plate casting method using the methodology proposed by Mali et al. [37]. Different aqueous dispersions were prepared with each of the starches. Starch was mixed with distilled water until reaching a concentration of $4 \%(w / w)$. The dispersion was heated on a heating plate (model 6795-220, CORNING, Monterrey, NL, Mexico) and kept under constant stirring (350 rpm) with overhead stirrer IKA (model RW 20 digital, WERKE, Wilmington, NC, USA), the dispersion was held at $85-90{ }^{\circ} \mathrm{C}$ for $15 \mathrm{~min}$. Subsequently, the starch dispersion was cooled to $70{ }^{\circ} \mathrm{C}$ and glycerol $(2 \%, w / w)$ as plasticizer was added [38]. The heating was maintained $15 \mathrm{~min}$ at this temperature under the same conditions of agitation. The filmogenic solutions with EA had the same starch and glycerol concentration and were prepared under the same conditions. However, glycerol was mixed with EA at three concentrations $(0.02 \%, 0.05 \%$ and $0.1 \%, w / w)$ based on total mass of film forming solution. This mixture was kept under constant stirring for $12 \mathrm{~h}$ before being added to the starch solution. Once the process is complete, the filmogenic solution (film-forming solution) was cooled to $60^{\circ} \mathrm{C}$ and emptied immediately in polystyrene Petri dishes $(\varnothing=15 \mathrm{~cm})$ using $40 \mathrm{~g} / \mathrm{box}$. Boxes with the filmogenic solutions were dried under laboratory condition ( $\mathrm{RH} \approx 45 \% \pm 5 \%$ and $25 \pm 1{ }^{\circ} \mathrm{C}$ ) until the formed film was peeled off easily from the plate $(\approx 72 \mathrm{~h})[24,39]$. Subsequently, the films were conditioned for $48 \mathrm{~h}$ in desiccators containing a saturated salt solution of $\mathrm{NaBr}(\mathrm{RH}=55 \% \pm 5 \%)$. After the conditioning, the properties of the films were characterized. The films obtained in the first stage from starch of apples harvested at 60, 70, 80 and 90 DAFB were abbreviated as: FILM-60, FILM-70, FILM-80 and FILM-90, respectively. The films made in the second stage, were obtained from starch of harvested apples at 70 DAFB. In this case, the film without EA was appointed as FILM-Control, while the films with $0.02 \%, 0.05 \%$ and $0.1 \%(w / w)$ of EA were identified as FILM-EA0.02\%, FILM-EA0.05\% and FILM-EA0.1\%, respectively.

\subsection{Films Characterization}

\subsubsection{Color}

The films tri-stimulus color was evaluated with a Minolta colorimeter CR-300 (Minolta, Osaka, Japan) with a diffuse illumination $/ 0^{\circ}$ viewing geometry and a pulsed xenon arc lamp (PXA). Readings were recorded in the color space in accordance with the CIELAB $\left(L^{*}, a^{*}, b^{*}\right)$ scale. Readings were taken in five random points on the surface of the films, using as background white standard used in the calibration of equipment. Moreover, the whiteness index (WI) of the films with EA and its control was measured according to the following equation [40]:

$$
W I=100-\sqrt{(100-L *)^{2}+a *^{2}+b *^{2}}
$$




\subsubsection{Optical Properties using Ultraviolet-visible (UV-vis) Spectroscopy}

The light barrier properties of the films evaluated as transparency was determined according to the methodology proposed by Luchese et al. [39]. Sample rectangles were cut and placed in the cell of a spectrophotometer (Evolution 300, Thermo Scientific, Waltham, MA, USA) and readings of the absorbance of the cell were made with the film at $600 \mathrm{~nm}$ taking the filmless cell as blank. Films transparency $(T)$ was calculated according to the following equation:

$$
\text { Transparency }(T)=\frac{A_{600}}{e}
$$

where $A_{600}$ is the absorbance of the cell with the film at $600 \mathrm{~nm}$ and $e$ is the film's thickness. According to the above, high absorbance values mean less transparency in the films. In the case of the films with EA, a sweep of the absorbance from 200 to $800 \mathrm{~nm}$ was performed. Five replicates were performed.

\subsubsection{Scanning Electron Microscopy}

The surface morphology of the films was evaluated by scanning electron microscope JEOL (JEE400, Tokyo, Japan). The film sample was adhered to the sample holder and covered with gold to make it conductive. Finally, micrographs were taken at acceleration potential of $5 \mathrm{kV}$ and a current intensity of $2 \mathrm{~mA}$.

\subsubsection{Thickness Measurement}

The film thickness (e) was measured using a digital micrometer Mitutoyo (model Coolant Proof 293-348, Kanagawa, Japan) with an accuracy of $0.001 \mathrm{~mm}$, the thickness was measured at 10 points randomly designated on the films.

\subsubsection{Moisture Content}

The moisture content was determined using the standard method of the International Association of Official Analytical Chemistry (AOAC) [41]. Samples of $0.5 \mathrm{~g}$ was weighed and dried in an oven Shel Lab (model 1370GM-2, Sheblon Manufacturing, Inc., Cornelius, OR, USA) at $105^{\circ} \mathrm{C}$ to constant weight with a variation of $0.0001 \mathrm{~g}(\approx 2.5 \mathrm{~h})$. This analysis was carried out five times and the moisture content was expressed as percentage of water in the film according to following equation:

$$
\text { Moisture }(\%)=\frac{W_{i}-W_{f}}{W_{i}} \times 100
$$

where, $W_{i}$ is the initial weight of the humid film and $W_{f}$ is the final weight of the dry film.

\subsubsection{Water Solubility}

The films solubility was determined according to the methodology proposed by Colla et al. [42] with slight modifications. Films were cut with sizes of $2 \times 3 \mathrm{~cm}^{2}$, which were dried to constant weight at $105^{\circ} \mathrm{C}$ during $2.5 \mathrm{~h}$. Each sample was placed in a beaker with $80 \mathrm{~mL}$ of distilled water. The samples were kept under gentle stirring $(\approx 60 \mathrm{rpm})$ in a Corning plate (Model PC-620D, New York, NY, USA) at room temperature $\left(23 \pm 3{ }^{\circ} \mathrm{C}\right)$ within $24 \mathrm{~h}$. Liquid together with the film was then filtered with filter paper (Whatman No. 1, pre-dried at $105^{\circ} \mathrm{C}$ to constant weight). Filter papers with film residues were dried again at $105{ }^{\circ} \mathrm{C}$ to constant weight to obtain the dry matter. The solubility was recorded as the percentage of dry material of the solubilized film $(\% S)$ for $24 \mathrm{~h}$ and was determined using the following equation:

$$
\text { Solubility }(\% S)=\frac{W_{i}-W_{f}}{W_{i}} \times 100
$$

where, $W_{i}$ is the weight of the dry film and $W_{f}$ is the weight of the dry sample after immersion in water. 


\subsubsection{Water Vapor Permeability (WVP)}

WVP was determined according to ASTM E-9680 [43] method, known as the cup method or test cell. The films were cut into circles and placed on cells containing approximately $12 \mathrm{~g}$ of dry silica gel (desiccant) to generate a relative humidity close to $0 \%$. Subsequently, the cells were placed in a desiccator containing a saturated $\mathrm{NaCl}$ solution to generate a $75 \% \mathrm{RH}$ at room temperature $\left(25 \pm 2{ }^{\circ} \mathrm{C}\right)$ solution. Weight variation of the cells over time was recorded, for which the cells every $60 \mathrm{~min}$ for at least $7 \mathrm{~h}$ were weighed. The recorded data were fit to a linear regression model and the transmission rate (TR) was calculated from the slope $\left(\mathrm{g} \mathrm{s}^{-1}\right)$ obtained from the straight line and the effective permeation area $\left(0.0031 \mathrm{~m}^{2}\right)$, while the WVP $\left(\mathrm{g} \mathrm{Pa}^{-1} \mathrm{~s}^{-1} \mathrm{~m}^{-1}\right)$ was determined according to the equation:

$$
\begin{gathered}
T R=\left(\frac{\Delta w}{\Delta t}\right) \frac{1}{A} \\
W V P=\frac{(T R)(e)}{\Delta P}
\end{gathered}
$$

where $\Delta w$ is the weight change in the cell ( $\mathrm{g}$ ) at the time $\Delta t(\mathrm{~s}), A$ is the exposed area of the film in the cell $\left(\mathrm{m}^{2}\right), e$ is the film thickness $(\mathrm{m})$ and $\Delta P$ is the gradient of the partial pressure of water vapor $(\mathrm{Pa})$ in the desiccator and inside the cell.

\subsubsection{Mechanical Properties}

Determinations were performed according to the methodology described by Mali et al. [44]. Ten strips $\left(60 \times 10 \mathrm{~mm}^{2}\right)$ were cut for each formulation; the thickness was measured at 10 random spots along each strip using a micrometer (Mitutoyo, Kobe, Japan). The films were subjected to a tensile stress in a TAXT-Plus texturometer (Stable Micro Systems, Surrey, UK) with a $30 \mathrm{~kg}$ load cell, following the guidelines of ASTM-882-95a [45]. Tensile tests were performed at a strain rate of $20 \mathrm{~mm} \mathrm{~min}-1$ and a distance between the clamping pincers $4 \mathrm{~cm}$. The tensile strength (TS) in MPa, the elongation at break $(\% E)$ in \% were recorded and the elasticity modulus (EM) in MPa was determined.

\subsubsection{X-ray Diffraction}

The diffractograms of the films were obtained by means of an X-ray diffractometer (Panalytical Xpert PRO, Almelo, OV, The Netherlands) with Ni-filtered $\mathrm{CuK} \alpha$ radiation at a voltage of $40 \mathrm{kV}$ and a current of $30 \mathrm{~mA}(\lambda=0.154 \mathrm{~nm})$, equipped with an $X^{\prime}$ Celerator detector. The diffractograms were collected within the scanning angle $2 \theta$ from $5^{\circ}$ to $40^{\circ}$ with a scanning speed of $1^{\circ} \mathrm{min}^{-1}$. The crystallinity of the films was calculated with the following equation:

$$
\text { Cristallinity }(\%)=\frac{A_{c}}{A_{c}+A_{a}} \times 100
$$

where, $A_{\mathcal{c}}$ is the area of the crystalline region and $A_{a}$ is the area of the amorphous region.

\subsubsection{Fourier Transform Infrared Spectroscopy (FTIR)}

The characterization of the films by FTIR was carried out with a Spectrum Two infrared spectrophotometer (Perkin Elmer Inc., Waltham, MA, USA) equipped with a universal module of attenuated total reflectance (ATR). The samples were placed in the sample holder for ATR and by means of a punch a pressure of $100 \pm 1 \mathrm{~N}$ was exerted on the sample. The vibrational transition frequencies were reported in transmittance (\%) according to the wave number $\left(\mathrm{cm}^{-1}\right)$ within the mid-infrared. An average of 34 sweeps per sample was recorded with a resolution of $4 \mathrm{~cm}^{-1}$ in the region from 450 to $4000 \mathrm{~cm}^{-1}$. The spectra were analyzed with Spectrum Two software version 10.4. 


\subsubsection{Thermogravimetric Analysis}

The thermal stability of the samples was assessed by thermogravimetric analysis according to procedure described by Teodoro et al. [46]. A TGA equipment was used (U600, TA Instruments, New Castle, DE, USA) under constant nitrogen flow $(20 \mathrm{~mL} / \mathrm{min})$. The amount of approximately 8-10 mg was weighted. Sample was heated from 25 to $800{ }^{\circ} \mathrm{C}$ at a speed of $20{ }^{\circ} \mathrm{C} \mathrm{min}-1$. The following temperatures for each sample were determinate: Maximum degradation temperature $\left(T_{\max }\right)$, the percentage of moisture contained at $100{ }^{\circ} \mathrm{C}(\mathrm{MC100})$, the temperature at which occurs a weight loss of $10 \%\left(T_{90}\right)$, as well as the extrapolated onset temperature $\left(T_{\text {onset }}\right)$ indicating the temperature at which weight loss begins and the residual mass at $800{ }^{\circ} \mathrm{C}$ extrapolated (MR800). The MC100, $T_{\text {onset }}$ and MR800 were estimated from the weight loss with respect to temperature (DTG curves).

\subsubsection{Antioxidant Capacity}

The films were kept under stirring in alcohol $(0.05 \mathrm{~g} / \mathrm{mL})$ for $12 \mathrm{~h}$ (in complete darkness). Subsequently, samples were centrifuged $\left(16,000 \times \mathrm{g}, 10 \mathrm{~min}, 5^{\circ} \mathrm{C}\right)$ and the supernatant was recovered and filtered (Whatman No. 1). The extracts obtained were used to evaluate antioxidant capacity. Evaluation of antioxidant capacity was performed by the 2,2-diphenyl-1-picrilhidracil method (DPPH) according to Brand-Williams et al. [47] with slight modifications. A methanolic solution of DPPH $(25 \mathrm{mg} / \mathrm{L})$ was prepared and adjusted its absorbance at $0.7 \pm 0.02 \mathrm{a} 490 \mathrm{~nm}$ since the molecule has its absorption maximum at this wavelength (according to a preliminary sweep). $20 \mu \mathrm{L}$ of the diluted sample (dilution factor 1:10) were placed in wells of a microplate and $280 \mu \mathrm{L}$ of the DPPH solution was added. Subsequently, the mixture was kept in the dark for $30 \mathrm{~min}$ and the absorbance was read on a microplate reader BIORAD at a wavelength of $490 \mathrm{~nm}$. Results were expressed as TEAC values, which translate as $\mu \mathrm{mol}$ Trolox equivalent (TE)/g dries film.

The antioxidant capacity was also determined by the assay of 2,2'-azino-bis (3-ethylbenzthiazolin)6-sulphonic acid (ABTS), for which the protocol described by Re et al. [48] was used. The ABTS cation radical was generated by mixing an aqueous solution of ABTS $(7 \mathrm{mM})$ with $88 \mu \mathrm{L}$ of a solution of potassium per sulfate $(140 \mathrm{mM}$ ) (final concentration of $2.45 \mathrm{mM})$. The mixture was allowed to stand for $16 \mathrm{~h}$ under conditions of total darkness. Subsequently, the solution of ABTS radical was diluted with methanol to obtain an absorbance of $0.70 \pm 0.05$ at $734 \mathrm{~nm}$. Ten $\mu \mathrm{L}$ of the diluted extract was placed in wells of a microplate and $290 \mu \mathrm{L}$ of the ABTS solution was added and its absorbance was measured at $734 \mathrm{~nm}$ in a BIORAD microplate reader. Antioxidant capacity was reported in the same manner as in DPPH protocol.

\subsection{Experimental Design}

The experiment was planned in two stages. In the first stage, apple starch films plasticized with glycerol were formulated and obtained. Apple starches were obtained from unripe fruits harvested at 60, 70, 80 and $90 \mathrm{DAFB}$. Once the films were obtained, their different properties were evaluated. Based on the results of its mechanical and barrier properties, the best film was chosen. In the second stage the effect of the incorporation of EA on the films selected in stage 1 was evaluated, considering its physicochemical, mechanical, barrier and antioxidant properties. In both stages, a completely randomized blocks design was used. The data were reported as the average of three replicates \pm standard error. The results were evaluated by analysis of variance one-way (ANOVA) and comparison of means was performed to detect significant differences $(p<0.05)$ by Tukey test. Data analysis was performed using SAS 9.0 (SAS Institute Inc., Cary, NC, USA) software.

\section{Results and Discussion}

\subsection{Physical Properties of Apple Starch Films Harvested at DAFB}

In Table 1 the physical, mechanical, barrier (WVP) and structural (crystallinity) properties of apple starch films harvested at 60, 70, 80 and 90 DAFB are shown. The thickness of the films did 
not show significant differences $(p>0.05)$, which was due to the fact that the preparation of films is standardized [38]. Moreover, this is an important variable that influences the mechanical and barrier properties. The moisture content of the films ranged significantly $(p<0.05)$ between $21.33 \%$ and $23.11 \%$, with the highest moisture content FILM-60.

Table 1. Physical, mechanical, crystallinity and water vapor permeability (WVP) properties of apple starch films harvested at different days after full bloom (DAFB).

\begin{tabular}{|c|c|c|c|c|}
\hline \multirow{2}{*}{ Analyzed Variable } & \multicolumn{4}{|c|}{ Film } \\
\hline & FILM-60 & FILM-70 & FILM-80 & FILM-90 \\
\hline Moisture (\%) & $23.11 \pm 0.49^{a}$ & $21.56 \pm 0.45^{b}$ & $22.84 \pm 0.39^{\mathrm{ab}}$ & $21.33 \pm 0.33^{b}$ \\
\hline Solubility (\%) & $18.55 \pm 1.01^{\mathrm{ab}}$ & $19.89 \pm 0.49^{a}$ & $21.36 \pm 0.89^{a}$ & $15.62 \pm 0.62^{b}$ \\
\hline Thickness ( $\mu \mathrm{m})$ & $102.30 \pm 4.39^{\mathrm{a}}$ & $100.28 \pm 2.74^{\mathrm{a}}$ & $99.33 \pm 1.94^{\mathrm{a}}$ & $96.73 \pm 1.48^{\mathrm{a}}$ \\
\hline Transparency & $1.14 \pm 0.02^{b}$ & $1.18 \pm 0.01^{\mathrm{b}}$ & $1.39 \pm 0.04^{\mathrm{a}}$ & $1.06 \pm 0.02 b^{c}$ \\
\hline Color & - & - & - & - \\
\hline$L^{*}$ & $95.73 \pm 0.09^{\mathrm{a}}$ & $95.81 \pm 0.14^{\mathrm{a}}$ & $95.77 \pm 0.11^{\mathrm{a}}$ & $95.46 \pm 0.19^{a}$ \\
\hline$a^{*}$ & $0.21 \pm 0.01^{\mathrm{ab}}$ & $0.19 \pm 0.01^{b}$ & $0.18 \pm 0.01^{b}$ & $0.25 \pm 0.01^{\mathrm{a}}$ \\
\hline$b^{*}$ & $2.04 \pm 0.05^{\mathrm{a}}$ & $2.14 \pm 0.05^{a}$ & $2.15 \pm 0.04^{a}$ & $2.02 \pm 0.04^{\mathrm{a}}$ \\
\hline Mechanical properties & - & - & - & - \\
\hline TS (MPa) & $4.70 \pm 0.15^{b}$ & $8.12 \pm 0.36^{\mathrm{a}}$ & $7.37 \pm 0.02^{\mathrm{a}}$ & $7.14 \pm 0.35^{\mathrm{a}}$ \\
\hline$\% E(\%)$ & $54.99 \pm 4.04^{\mathrm{a}}$ & $52.12 \pm 4.30^{\mathrm{a}}$ & $56.59 \pm 0.56^{\mathrm{a}}$ & $56.35 \pm 2.79^{a}$ \\
\hline$E M(\mathrm{MPa})$ & $0.92 \pm 0.14^{c}$ & $3.10 \pm 0.27^{\mathrm{a}}$ & $2.03 \pm 0.11^{\mathrm{ab}}$ & $1.71 \pm 0.19 \mathrm{bc}$ \\
\hline Crystallinity (\%) & $28.29 \pm 1.25^{\mathrm{a}}$ & $29.66 \pm 2.52^{\mathrm{a}}$ & $33.50 \pm 1.82^{\mathrm{a}}$ & $28.47 \pm 1.20^{\mathrm{a}}$ \\
\hline$W V P \times 10^{-11}\left(\mathrm{~g} \mathrm{~m}^{-1} \mathrm{~s}^{-1} \mathrm{~Pa}^{-1}\right)$ & $11.97 \pm 1.09^{\mathrm{a}}$ & $6.77 \pm 0.85^{b}$ & $7.36 \pm 0.29^{b}$ & $9.71 \pm 0.25^{\mathrm{ab}}$ \\
\hline
\end{tabular}

Values represent the average of three repetitions \pm standard error; Different letters in each row are significantly different $(p<0.05)$; DAFB: days after full bloom; TS: tensile strength; $\% E$ : elongation at break; $M E$ : elasticity modulus; WVP: water vapor permeability.

The solubility of the films ranged between $15.62 \%$ and $21.36 \%$; while the moisture content of the films did not affect their solubility. These values were minor than reported in sago starch films $(\sim 25.2 \%)$ [49] and cassava starch films (28\%) [50]. High values of solubility film have been related to a high biodegradability, this is an advantage in foods covered with edible coatings that will be cooked. However, low solubility is required in foods that are stored for a long time [49]. Moreover, the solubility is an important factor to take into account in the migration of active substances from the packaging to the food matrix [6].

The optical properties are another advantage of starch films, since being practically colorless allow consumers to examine the food inside the package. The transparency of the films ranged between 1.06 and 1.39 , equivalent to values of internal transmittance of $70 \%-75 \%$. The transparency of the starch films was similar to that of synthetic films such as low density polyethylene (3.05), oriented polypropylene (1.67) and polyester (1.51) [51], which suggests that they have enough transparency to be used as edible packaging. The tensile strength (TS) (4.70-8.12 MPa) and the elastic modulus (EM) (0.92-3.10 MPa) varied significantly and both mechanical properties presented the following descending order: FILM-70 > FILM-80 > FILM-90 > FILM-60. The elongation at break (\%E) did not present significant differences ranging between $52.12 \%$ and $56.59 \%$ with the following decreasing order: FILM-80 > FILM-90 > FILM-60 > FILM-70. This was due to the fact that the mechanical properties are influenced by the microstructure of the films, as well as by the crystallinity of their components.

The crystallinity of the films evaluated fluctuated between $28.29 \%$ and $33.50 \%$ without presenting significant differences $(p>0.05)$ with the following descending order: FILM-80 > FILM-70 > FILM-90 $>$ FILM-60. Just at the sample FILM-60 a feasible relation between the crystallinity and the lower numerical values was observed for TS and ME. Finally, the water vapor permeability (WVP) varied significantly among the tested films (Table 1). The highest values for WVP were observed in FILM-60 and FILM-90 with 11.97 and $9.71 \times 10^{-11} \mathrm{~g} \mathrm{~m}^{-1} \mathrm{~s}^{-1} \mathrm{~Pa}^{-1}$, respectively. On the other hand, the lowest values were for FILM-70 and FILM-80 with a WVP of 6.77 and $7.36 \times 10^{-11} \mathrm{~g} \mathrm{~m}^{-1} \mathrm{~s}^{-1} \mathrm{~Pa}^{-1}$, respectively. These values were lower than those reported in films of commercial corn's starch 
$\left(19.2 \times 10^{-11} \mathrm{~g} \mathrm{~m}^{-1} \mathrm{~s}^{-1} \mathrm{~Pa}^{-1}\right)$ [52] and yam $\left(18.10 \times 10^{-11} \mathrm{~g} \mathrm{~m}^{-1} \mathrm{~s}^{-1} \mathrm{~Pa}^{-1}\right)$ [37] plasticized with glycerol. In relation to these results it is important to point out that an objective comparison of WVP can be difficult, because this variable depends on the botanical source (amylose/amylopectin ratio), amount of plasticizer and moisture gradient used in the determination of WVP [27]. The behavior of WVP is also influenced by the microstructure of the film, because the porosity and possible cracks increase the values of WVP $[1,53]$. When compared with synthetic plastics such as polyethylene, one of the great disadvantages of starch films is their high WVP, which limits their ability to maintain the quality of food during storage. Therefore, taking into account the highest values of TS, ME and the lowest value of WVP, the formulation FILM-70 was considered as the most appropriate to assess the effect of the addition of ellagic acid (EA) on its physicochemical, mechanical, barrier and antioxidants properties. It is important to note that there were no significant differences between the mechanical properties of FILM-70 and FILM-80. Nevertheless, late fruit hand-thinning is practiced at until 70 DAFB in our region, thus these immature apples are considered a waste that can be used as an unconventional source of starch.

\subsection{Characterization of Films with Ellagic Acid (EA) in the FILM-70 Formulation}

\subsubsection{Scanning Electron Microscopy (SEM) Analysis}

In Figure 1 the micrographs of the surface of apple's starch films without EA (FILM-Control) and EA at different concentrations $(0.02 \%, 0.05 \%$ and $0.1 \%$ ) are shown. The absence of EA yielded films with a compact and smooth surface, while the addition of EA to different concentrations promoted the formation of rough surfaces. Furthermore, the presence of aggregates of EA on the surface was evident, which indicated that there was no adequate dispersion of the EA in the polymeric matrix because the EA, besides being insoluble in water, is very poorly soluble in many organic solvents such as alcohol [34], so it probably requires the use of other types of solvents as the basic solutions [30]. This behavior was similar to that observed by Kim et al. [30] who formulated autoclaved chitosan films with EA. These authors observed that the surface became rough by increasing the concentration of EA. The morphology and microstructure of the films is of extreme importance, since it has a direct effect on the other properties [37].

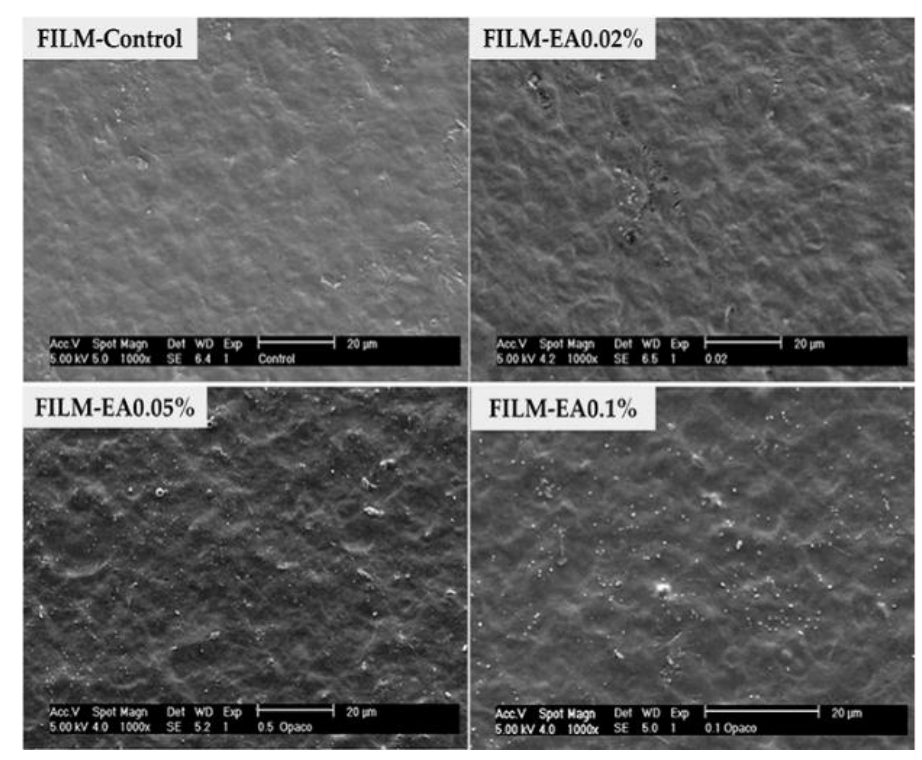

Figure 1. Surface morphology of apple starch films without ellagic acid (FILM-Control) and with ellagic acid (EA) added to $0.02 \%$ (FILM-EA0.02\%), 0.05\% (FILM-EA0.05\%) and 0.1\% (FILM-EA0.1\%). 


\subsubsection{Color and UV-vis Spectroscopy}

The optical properties (transparency and color) varied significantly $(p<0.05)$ when EA was added in films formulation FILM-70 (Table 2). The brightness of the films $\left(L^{*}\right)$ decreased with the addition and the increase in the concentration of EA, which produced a slight darkening in the films, this was in agreement with the decrease in the whiteness index (WI). The variable $a^{*}$ ranged from positive values (control film) to negative values (green tonality) when adding EA. The variable $b^{*}$ was always maintained with positive values, fluctuating between 2.73 and 14.48 , following the descending order FILM-EA0.1\% > FILM-EA0.05\% > FILM-EA0.02\% > FILM-Control. This indicated that the films tended towards the yellow tonality (values $+b^{*}$ ) when adding and increasing the EA concentration (Figure 2a).

Table 2. Physical, mechanical, crystallinity and WVP properties of apple starch films without ellagic acid (FILM-Control) and with ellagic acid (EA) added to 0.02\% (FILM-EA0.02\%), 0.05\% (FILM-EA0.05\%) and $0.1 \%$ (FILM-EA0.1\%).

\begin{tabular}{|c|c|c|c|c|}
\hline \multirow{2}{*}{ Analyzed Variable } & \multicolumn{4}{|c|}{ Film } \\
\hline & FILM-Control & FILM-EA0.02\% & FILM- EA0.05\% & FILM-EA0.1\% \\
\hline Transparency & $1.51 \pm 0.09 \mathrm{~d}$ & $3.73 \pm 0.27^{c}$ & $8.46 \pm 0.194^{b}$ & $17.45 \pm 0.55^{\mathrm{a}}$ \\
\hline Color & - & - & - & - \\
\hline$L^{*}$ & $95.87 \pm 0.07^{\mathrm{a}}$ & $95.11 \pm 0.13^{b}$ & $94.13 \pm 0.17^{\mathrm{c}}$ & $92.32 \pm 0.14^{\mathrm{d}}$ \\
\hline$a^{*}$ & $0.22 \pm 0.01^{\mathrm{a}}$ & $-0.82 \pm 0.03^{b}$ & $-1.24 \pm 0.03^{c}$ & $-1.31 \pm 0.02^{c}$ \\
\hline$b^{*}$ & $2.73 \pm 0.06^{\mathrm{d}}$ & $6.77 \pm 0.20^{c}$ & $10.52 \pm 0.29^{b}$ & $14.48 \pm 0.18^{\mathrm{a}}$ \\
\hline WI & $95.04 \pm 0.08^{a}$ & $91.60 \pm 0.24^{b}$ & $87.89 \pm 0.33^{c}$ & $83.8 \pm 83.56^{\mathrm{d}}$ \\
\hline Moisture (\%) & $23.83 \pm 0.88^{a}$ & $21.52 \pm 0.49^{a b}$ & $22.92 \pm 0.49^{a b}$ & $21.23 \pm 0.32^{b}$ \\
\hline Solubility (\%) & $20.51 \pm 0.12^{b}$ & $21.79 \pm 0.43^{\mathrm{ab}}$ & $22.02 \pm 0.93^{a}$ & $23.79 \pm 0.20^{a}$ \\
\hline Thickness $(\mu \mathrm{m})$ & $102.79 \pm 3.67^{\mathrm{a}}$ & $102.79 \pm 3.67^{\mathrm{a}}$ & $104.42 \pm 3.61^{\mathrm{a}}$ & 103. $53 \pm 4.17^{\mathrm{a}}$ \\
\hline Mechanical properties & - & - & - & - \\
\hline TS $(\mathrm{MPa})$ & $6.51 \pm 0.18^{b}$ & $8.98 \pm 0.28^{a}$ & $9.63 \pm 0.52^{a}$ & $8.21 \pm 0.45^{\mathrm{a}}$ \\
\hline$\% E(\%)$ & $65.11 \pm 2.98^{a}$ & $62.48 \pm 2.98^{a b}$ & $56.91 \pm 3.01 \mathrm{ab}$ & $52.44 \pm 1.21^{\mathrm{b}}$ \\
\hline$E M(\mathrm{MPa})$ & $1.79 \pm 0.19^{c}$ & $2.78 \pm 0.13^{b c}$ & $4.58 \pm 0.42^{\mathrm{a}}$ & $3.63 \pm 0.32^{\mathrm{ab}}$ \\
\hline Crystallinity (\%) & $28.81 \pm 1.69^{\mathrm{a}}$ & $28.63 \pm 0.64^{a}$ & $28.99 \pm 0.27^{\mathrm{a}}$ & $31.39 \pm 1.66^{\mathrm{a}}$ \\
\hline$W V P \times 10^{-11}\left(\mathrm{~g} \mathrm{~m}^{-1} \mathrm{~s}^{-1} \mathrm{~Pa}^{-1}\right)$ & $6.59 \pm 0.28^{b}$ & $7.46 \pm 0.34^{\mathrm{a}}$ & $6.65 \pm 0.19 \mathrm{ab}$ & $6.35 \pm 0.22^{b}$ \\
\hline
\end{tabular}

Values represent the average of three repetitions \pm standard error; Different letters in each row are significantly different $(p<0.05)$; DAFB, days after full bloom; WI, whiteness index; TS: tensile strength; $\% E$ : elongation at break; EM: elasticity modulus; WVP: water vapor permeability.

On the other hand, transparency of the films increased between 1.51 and 17.45, according to the following order FILM-EA0.1\% > FILM-EA0.05\% > FILM-EA0.02\% > FILM-Control. It is important to indicate that higher values in transparency result in materials that reduce transmission to light (more opaque). This characteristic can be observed in the Figure 2a, the increase in EA content promoted more opaque starch films than control film. Figure $2 \mathrm{~b}$ shows the optical transparency of films evaluated a in the wavelength region of $200-800 \mathrm{~nm}$, the FILM-Control virtually allowed light transmission between $60 \%$ and $70 \%$ under the visible light region. This light transmission decreased dramatically to $17 \%$ to $48 \%, 1 \%$ to $20 \%$ and $0.1 \%$ to $6 \%$ with addition of EA at 0.02 (FILM-EA0.02), 0.05 (FILM-EA0.05) and 0.1\% $w / w$ (FILM-EA0.1), respectively. UV-vis absorption curves measured from 200 to 800 are shown in Figure 2c, all the films could prevent the UV transmission compared to the film control, because of the addition of EA promoted significant $(p<0.05)$ high absorption of light. Moreover, in the UV-vis absorption spectrum, the presence of EA in the films promoted the apparition of absorption peaks at 370 and $400 \mathrm{~nm}$ and the intensity of peaks increased with increasing EA content in the films. The peak absorption band $370 \mathrm{~nm}$ is characteristic to the presence of flavonols, while the absorption band $400 \mathrm{~nm}$ exhibited the presence of the lactone ring in the EA structure [54]. Within UV radiation, the one that causes the most damage to sensitive components (pigments, vitamins, some enzymes, among others) present in food, is UV-A (ultraviolet light of long wavelength, 315-400 nm) [49]. The incorporation of EA significantly increased the absorption of UV-A, which was almost completely blocked with the addition of EA at the concentrations of $0.05 \%$ 
(FILM-EA0.05\%) and 0.1\% (FILM-EA0.1\%) in films (Figure 2b). Generally, food packaging requires transparent packaging; however, mostly opaque materials can protect those components of food that are sensitive to light, thus maintaining their quality.
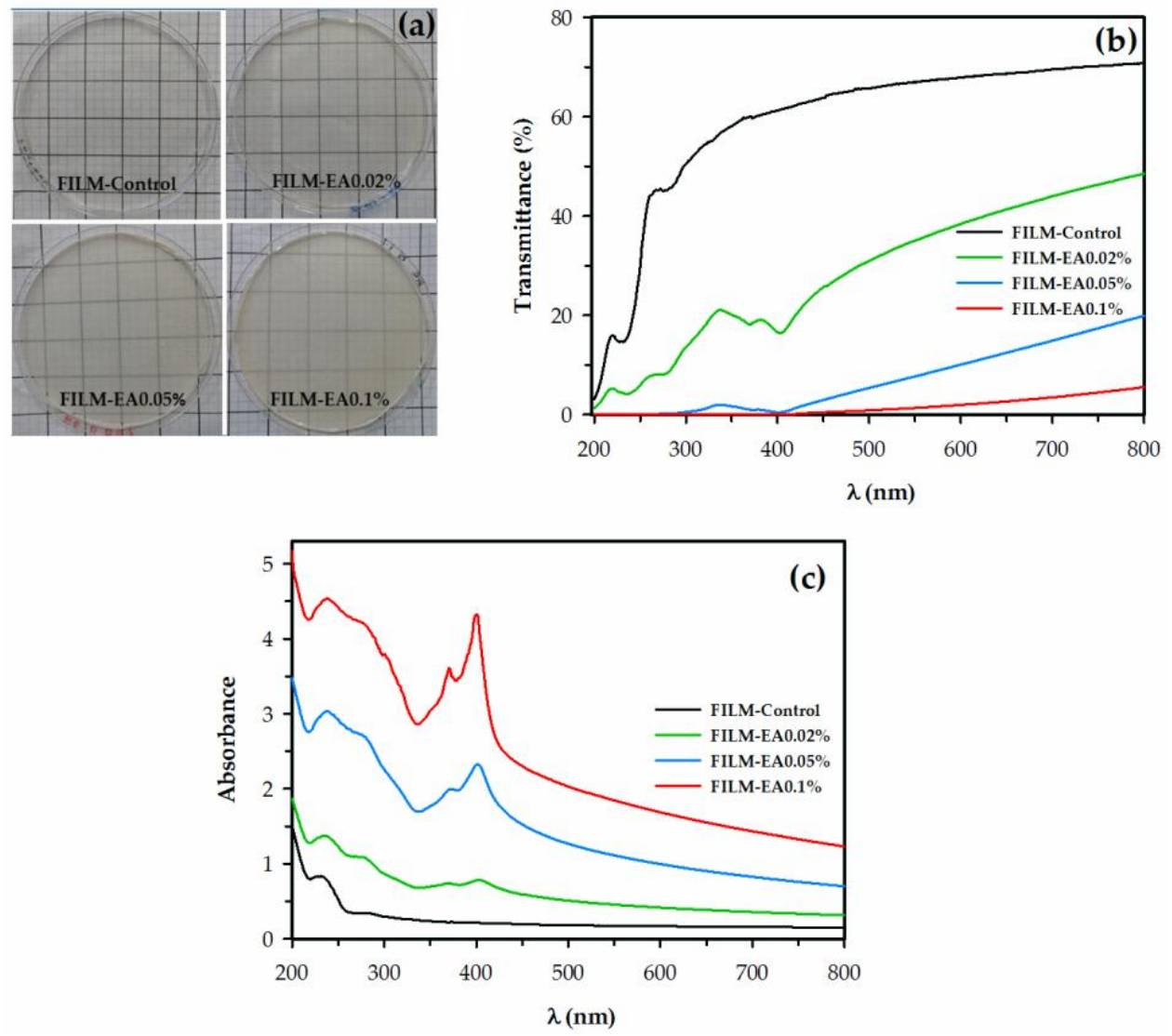

Figure 2. (a) Digital images, (b) UV-vis transmittance and (c) UV-vis absorbance spectra of apple starch films without ellagic acid (FILM-Control) and with ellagic acid (EA) added to $0.02 \%$ (FILM-EA0.02\%), $0.05 \%$ (FILM-EA0.05\%) and 0.1\% (FILM-EA0.1\%).

\subsubsection{Moisture Content and Thickness of the Films}

There were no significant differences $(p>0.05)$ in the thickness of the films (Table 2), so the addition of EA did not influence this determination. Thickness uniformity can be taken as an indicator that the process for preparing film was standardized, allowing control this feature. The film thickness is important because it influences the mechanical and barrier properties of these materials. Compared with the film without EA (FILM-Control), the moisture content only decreased $(p<0.05)$ when $0.1 \%$ of EA was added (FILM-EA0.1\%), going from $23.83 \%$ to $21.23 \%$ (Table 2), with a decrease of $11 \%$. These values were higher than those reported by Piñeros-Hernandez et al. [1] in starch films with rosemary extract $(19.4 \%-19.8 \%)$. Moreover, they were considerably lower than those reported by Medina-Jaramillo et al. [50] in films from cassava starch with green tea (25.3\%) and basil (28.6\%) extract. Both researchers observed surface hydrophobicity after adding extracts rich in phenols.

\subsubsection{Solubility and Water Vapor Permeability (WVP)}

The solubility of the films is shown in Table 2, expressed as a percentage of dry matter soluble in water for $24 \mathrm{~h}$. The solubility of the films ranged from $20.51 \%$ to $23.59 \%$, with the following order FILM-EA0.1\% > FILM-EA0.05\% > FILM-EA0.02\% > FILM-Control. In comparison with the film without EA, the solubility increased significantly by $16 \%$ when $0.05 \%-0.1 \%$ of EA was incorporated. This behavior could be explained based on the results reported by Kim et al. [30], who observed that 
increasing the concentration of EA in chitosan films also decreased the contact angle on its surface, promoting a more hydrophilic character. The solubility of the films is related to increased water resistance. The water vapor permeability (WVP) is a measure of the amount of vapor molecules of water passing through the film. Compared to FILM-Control, only FILM-EA0.05\% increased the WVP from 6.59 to $7.46 \times 10^{-11} \mathrm{~g} \mathrm{~m}^{-1} \mathrm{~s}^{-1} \mathrm{~Pa}^{-1}$, showing an increase of $13 \%$. WVP values reported in this paper are within those reported by Nouri and Mohammadi [49] and Piñeros-Hernandez et al. [1] in films of sago starch and cassava starch, respectively. As mentioned above, the incorporation EA in chitosan films promoted a character hydrophilic in their surface, so that based on the results of solubility shown in the Table 2, is very likely that such behavior is also present in the films obtained in this study. Therefore, the WVP values would be expected to increase with the EA concentration. It is possible that the presence of scattered particles in the films (Figure 1) will affect mass transfer in the contact area [25]; however, more studies are needed in this regard. The barrier properties of the films are related to their microstructure [37]. Figure 1 shows a mostly uniform surface in FILM-Control and only cracks were observed on the surface of the films with $0.02 \%$ of EA, which promoted an increase in the values of WVP. Piñeros-Hernandez et al. [1] observed cracks in the surface of starch films with $10 \%$ rosemary extract only when the magnification was $2000 \times$. In addition, cross-sectional micrographs generate more information about the microstructure of these materials and impact properties (data not shown). In general, the solubility and values of WVP films should be low or minimum to preserve food during storage; however, high solubility would be an advantage if these materials are to be used as food coatings [49].

\subsubsection{Mechanical Properties}

The tensile strength (TS), elastic modulus (EM) and elongation at break $(\% E)$ of the starch films without and with EA are presented in Table 2. Compared with FILM-Control, the addition of EA affected significantly $(p<0.05)$ all the mechanical properties. Tensile strength increased to $38 \%$ from $6.51 \mathrm{MPa}$ (FILM-control) to $8.98 \mathrm{MPa}$ by adding $0.02 \%$ of EA in the formulation (FILM-EA0.02\%). By increasing the concentration of EA were no significant differences between active films. In comparison with FILM-Control, elongation at break remained constant at EA concentrations of $0.02 \%$ (FILM-EA $0.02 \%$ ) and $0.05 \%$ (FILM-EA0.05\%). However, increasing the concentration of EA to $0.1 \%$ (FILM-EA0.1\%), \%E experienced a decrease of $19 \%$. EA concentration did not affect $\% \mathrm{E}$ in active films. Moreover, the elasticity modulus unchanged $(p>0.05)$ when comparing FILM-Control and FILM-EA0.02\%; however, the rigidity (EM) of the films increased by 155 and $102 \%$ by increasing the concentration of $0.05 \%$ EA (FILM-AE0.05\%) and $0.1 \%$ (FILM-AE0.1\%), respectively. On the other hand, the micrographs of the films (Figure 1) showed that FILM-Control presented, at least on the surface, a more compact structure (uniform and homogeneous) than the active films (films with EA). Theoretically, a more compact surface would provide better mechanical properties; however, the inclusion of EA in the structure generated rougher surfaces presenting mechanical properties (except \%E) higher than those in FILM-Control. This implies that there was an interaction between the EA and the starch, such as the possible formation of ester bonds during the gelatinization process $[1,55,56]$ or hydrogen bonding interactions [56,57]; however, further investigation needs to be done about this physicochemical phenomenon.

\subsubsection{X-ray Diffraction and Crystallinity}

The X-ray diffraction patterns of the developed films are shown in Figure 3. The film FILM-Control presented mostly pronounced peaks at approximately $2 \theta=17^{\circ}, 19.5^{\circ}$ and $22.2^{\circ}$. Compared FILM-Control, films added with EA showed the same peaks of crystallinity. However, from concentrations higher than $0.02 \%$ of EA (i.e., in films FILM-EA $0.05 \%$ and FILM-0.1\%) a peak of crystallinity was observed at $2 \theta=12.3^{\circ}$. In the film with the highest concentration of EA (FILM- $0.1 \%$ ), another peak of crystallinity appeared at $2 \theta=28.3^{\circ}$. Kim et al. [30] obtained diffractograms of EA powder and added in chitosan films, the peaks of crystallinity in $2 \theta=13.2^{\circ}$ and $28.3^{\circ}$ were reported for EA powder and appeared in 
chitosan films with EA concentrations higher than $0.1 \%$. However, in comparison with the control film, the presence of the peaks of crystallinity of the EA did not significantly affect $(p>0.05)$ the crystallinity of the films, ranging between $26.63 \%$ and $31.39 \%$ (Table 2) with the following order FILM- $0.1 \%$ > FILM-EA0.05\% > FILM-Control > FILM-EA0.02\%.

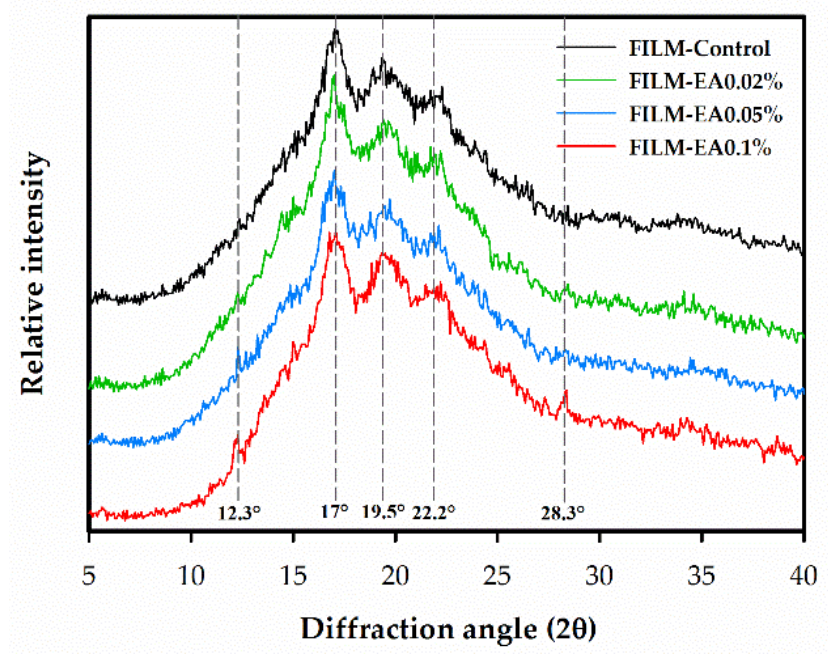

Figure 3. X-ray diffractograms of apple starch films without ellagic acid (FILM-Control) and with ellagic acid (EA) added to 0.02\% (FILM-EA0.02\%), 0.05\% (FILM-EA0.05\%) and 0.1\% (FILM-EA0.1\%).

\subsubsection{Fourier Transform Infrared Spectroscopy}

Fourier transform infrared (FTIR) spectra obtained from the apple starch film without EA (FILM-Control) and with EA (FILM-EA0.02\%, FILM-EA0.05\% and FILM-EA0.1\%) are shown in Figure 4. These spectra were compared to determine the feasible chemical interactions between the components of the films (starch, glycerol, water and EA). It can be seen that in the wave number $(1 / \lambda)$ from 4000 to $450 \mathrm{~cm}^{-1}$ (Figure 4a) all the spectra showed the characteristic peaks for the stretching of the $\mathrm{OH}$ bond $\left(3300 \mathrm{~cm}^{-1}\right)$ and the stretching of the $\mathrm{CH}$ bonds associated with the glucose ring $\left(2922 \mathrm{~cm}^{-1}\right)$ [58]. Within the region of the fingerprint $\left(1 / \lambda=400-1250 \mathrm{~cm}^{-1}\right)$ [17] characteristic peaks were observed at $1149 \mathrm{~cm}^{-1}, 1078 \mathrm{~cm}^{-1}$ and $1004 \mathrm{~cm}^{-1}$, representative of $\mathrm{C}-\mathrm{O}-\mathrm{C}$ and $\mathrm{C}-\mathrm{OH}$ stretches in the glycosidic bonds of polysaccharides [59]. In the films with EA, starting at a concentration of $0.05 \%$ (FILM-EA0.05\%) the appearance of a new peak was observed at $1507 \mathrm{~cm}^{-1}$, which was intensified at a concentration of $0.1 \%$ (FILM-EA0.1\%). Previously similar behaviors have been observed in chitosan films with different concentrations of EA $(0.05,0.1$ and $0.5 \%)$ and this was related to the stretching of the $\mathrm{C}=\mathrm{C}$ bonds present in the aromatic compounds [30]. These results are similar to those reported by Piñeros-Hernandez et al. [1], who obtained cassava starch films added with rosemary extract. FILM-Control and FILM-EA0.02\% film had a clearly defined signal at $1645 \mathrm{~cm}^{-1}$, which was the result of vibrations bending of the $\mathrm{OH}^{-}$groups of water absorbed in the amorphous region of the starch molecule [60]. However, in Figure $4 \mathrm{~b}$ it can be seen that in films FILM-EA0.05\% a new peak was developed at $1702 \mathrm{~cm}^{-1}$, which was more intense in FILM-EA0.1\%. This peak is related to the stretching of the ester bonds $(\mathrm{C}=\mathrm{O})[1,55,56]$. Moreover, the new bands at 1620 and $1580 \mathrm{~cm}^{-1}$ in FILM-EA0.1\% (Figure 4b) have been related with aromatic rings [61]. This suggests that there was possibly a chemical interaction between starch and ellagic acid, which could have caused the observed variations in the mechanical properties of films with EA. 

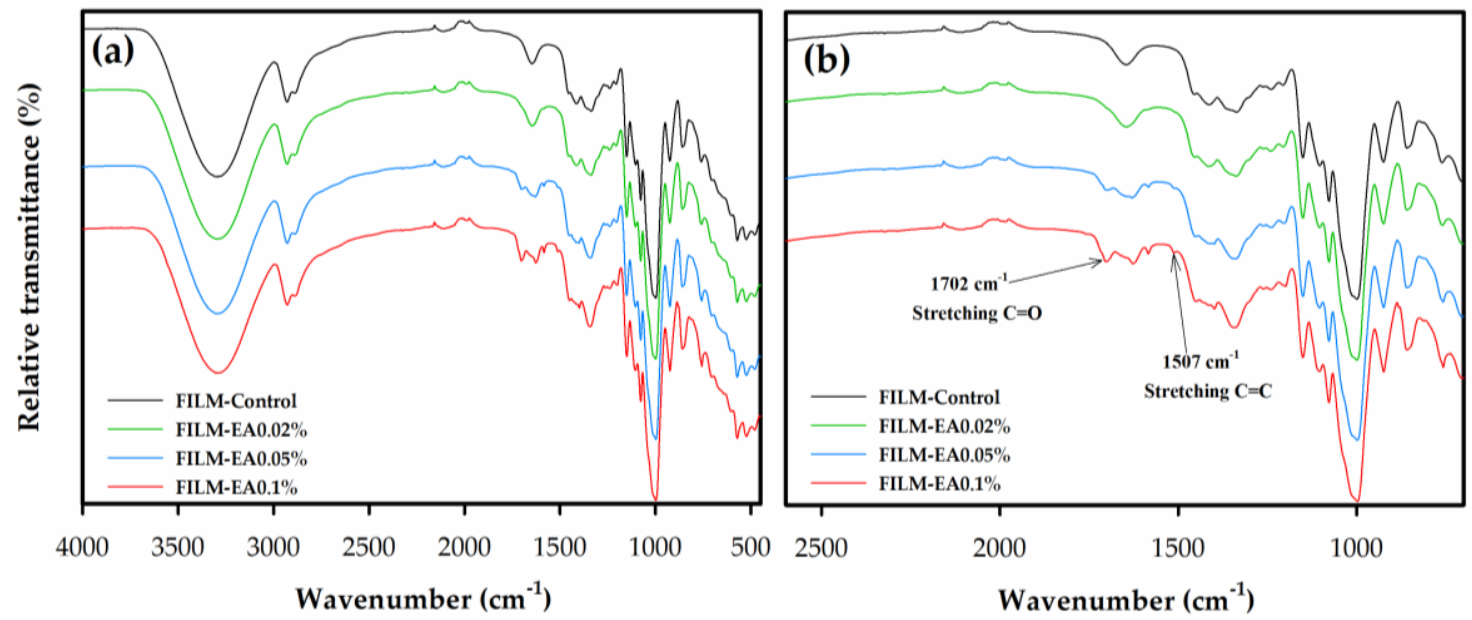

Figure 4. Fourier transform infrared (FTIR) spectra evaluated in: (a) 4000-650 $\mathrm{cm}^{-1}$ and (b) $2600-700 \mathrm{~cm}^{-1}$ of apple starch films without ellagic acid (FILM-Control) and with ellagic acid (EA) added to $0.02 \%$ (FILM-EA0.02\%), 0.05\% (FILM-EA0.05\%) and 0.1\% (FILM-EA0.1\%).

\subsubsection{Thermogravimetric Analysis}

The effect of EA addition on the thermal stability of the FILM-70 films can be seen in the graphs of thermogravimetric analysis (TGA) shown in Figure 5. In the thermograms, three stages of weight loss versus temperature were noted, this behavior has been previously reported for starch films plasticized with glycerol [13,29]. The first stage occurred between 55 and $150{ }^{\circ} \mathrm{C}$, this decrease in initial weight has been associated with the loss of water and other low molecular weight compounds [62]. Weight loss in the second stage $\left(150-280^{\circ} \mathrm{C}\right)$ has been associated with the decomposition of the glycerol-rich phase, which also contains starch [29]. Finally, the weight loss observed in the last stage $\left(280-350{ }^{\circ} \mathrm{C}\right)$ was a result of the breakdown of carbohydrates [29,58].

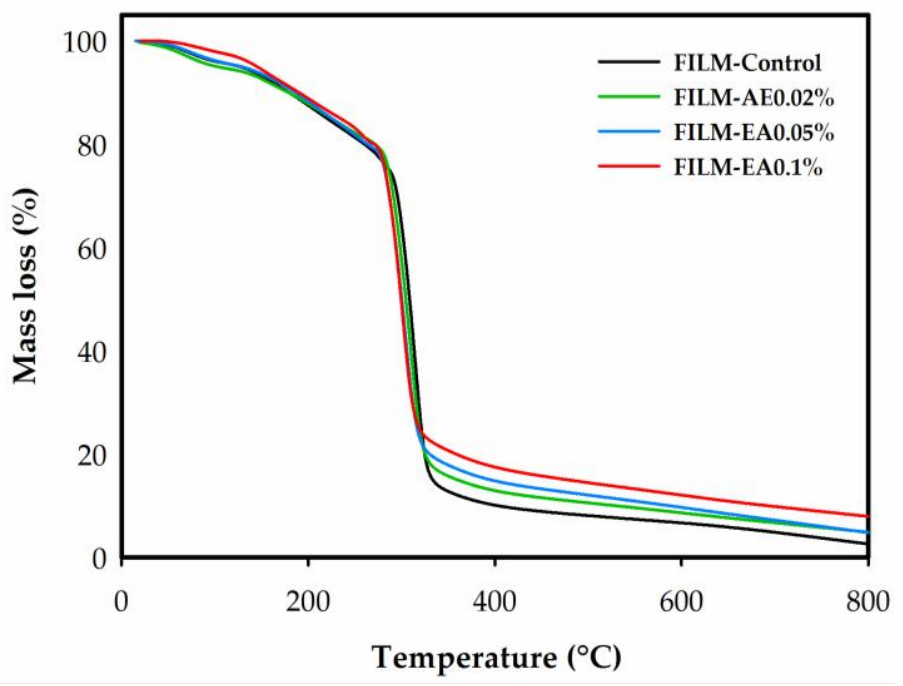

Figure 5. Thermogravimetric curves of apple starch films without ellagic acid (FILM-Control) and with ellagic acid (EA) added to $0.02 \%$ (FILM-EA0.02\%), 0.05\% (FILM-EA0.05\%) and 0.1\% (FILM-EA0.1\%).

On the other hand, within the thermal variables evaluated (Table 3), it was shown that the temperature at which $10 \%$ of the weight of the sample was lost (T90) did not present a significant difference $(p>0.05)$ for all the films, which indicated that the thermal stability was not affected by the incorporation of $\mathrm{AE}$ in the evaluated concentrations [46]. No significant differences were observed $(p>0.05)$ in the percentage of humidity contained at $100{ }^{\circ} \mathrm{C}(\mathrm{MC} 100)$, with the lowest values 
corresponding to the films FILM-AE0.05\% and FILM-AE0.1\%, which was related to the moisture content of those films (Table 2). The $T_{\text {onset }}$ and $T_{\max }$ temperatures were significantly higher in the control film, which has been linked to the low interaction between the matrix and the additive [63]. The residual mass (residue) is related to the nature of the additives, inorganic components and impurities further combustion in inert atmosphere $\left(\mathrm{N}_{2}\right)$ cannot even allow complete combustion of organic components [63].

Table 3. Thermal variables determined from film thermograms of apple starch films without ellagic acid (FILM-Control) and with ellagic acid (EA) added to 0.02\% (FILM-EA0.02\%), 0.05\% (FILM-EA0.05\%) and $0.1 \%$ (FILM-EA0.1\%).

\begin{tabular}{cccccc}
\hline Film & $\boldsymbol{T}_{\mathbf{9 0}}\left({ }^{\circ} \mathbf{C}\right)$ & MC100 (\%) & $\boldsymbol{T}_{\text {onset }}\left({ }^{\circ} \mathbf{C}\right)$ & $\boldsymbol{T}_{\max }\left({ }^{\circ} \mathbf{C}\right)$ & RM800 \\
\hline FILM-Control & $176.83 \pm 1.08^{\mathrm{a}}$ & $4.11 \pm 0.22^{\mathrm{a}}$ & $291.20 \pm 0.76^{\mathrm{a}}$ & $313.77 \pm 0.83^{\mathrm{a}}$ & $1.63 \pm 0.62^{\mathrm{a}}$ \\
FILM-0.02\%EA & $170.86 \pm 6.89^{\mathrm{a}}$ & $5.02 \pm 0.47^{\mathrm{a}}$ & $280.63 \pm 2.33^{\mathrm{b}}$ & $309.16 \pm 1.27^{\mathrm{b}}$ & $4.61 \pm 0.15^{\mathrm{b}}$ \\
FILM-0.05\%EA & $180.30 \pm 3.10^{\mathrm{a}}$ & $3.95 \pm 0.21^{\mathrm{a}}$ & $278.37 \pm 0.42^{\mathrm{b}}$ & $302.63 \pm 0.33^{\mathrm{c}}$ & $5.31 \pm 0.33^{\mathrm{b}}$ \\
FILM-0.10\%EA & $179.86 \pm 14.68^{\mathrm{a}}$ & $3.70 \pm 1.22^{\mathrm{a}}$ & $278.50 \pm 0.80^{\mathrm{b}}$ & $301.29 \pm 0.01^{\mathrm{c}}$ & $7.58 \pm 0.29^{\mathrm{c}}$ \\
\hline
\end{tabular}

Values represent the average of three repetitions \pm standard error. Different letters in each column are significantly different $(p<0.05)$.

\subsubsection{Antioxidant Capacity}

The antioxidant capacity of starch films with different concentrations of EA is presented in Figure 6. The antioxidant capacity of the films, determined by DPPH and ABTS, showed a similar behavior by both methods, with significant increases in antioxidant capacity with the increase of EA in the films. Based on films with $0.02 \% \mathrm{EA}$, with the DPPH protocol, antioxidant capacity increased 3.2 and 7.1 times in films with $0.05 \%$ and $0.1 \%$ EA, while with the ABTS protocol the increase was 3.02 and 5.7 times, respectively. The results obtained in this study were similar to those reported by López-Mata et al. [40] in chitosan films added with carvacrol; however, the concentrations used by these authors are up to 15 times larger, which is a clear evidence that the $\mathrm{AE}$ (compared to other substances) is a powerful antioxidant even at low concentrations as $0.02 \%(w / v)$. These results indicate that apple starch films added with EA may have antioxidant capacity even at the concentration of $0.02 \%$ $(w / v)$. However, it is necessary to carry out studies on the kinetics of release of the antioxidant agent from the films, which is determined by the type of antioxidant and the nature of the food simulant [6].

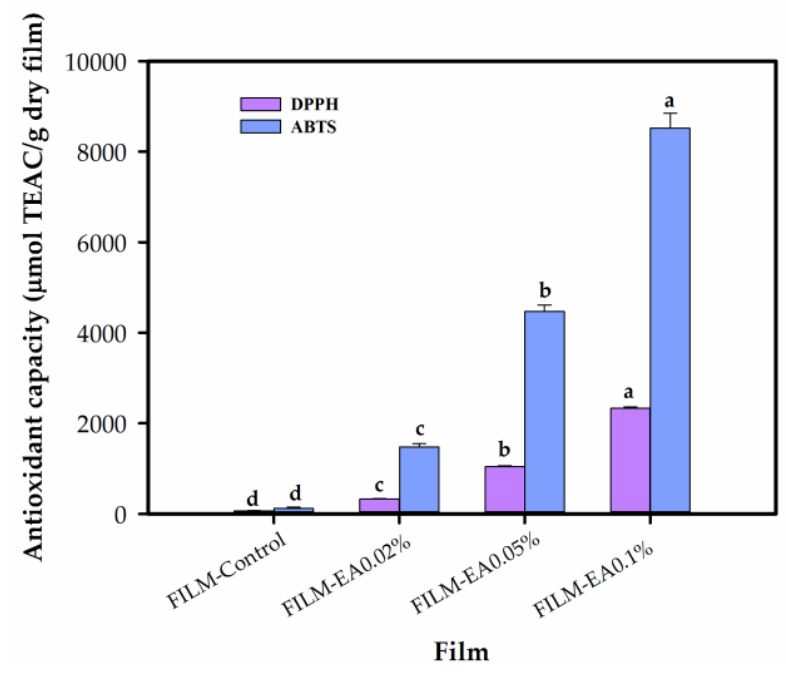

Figure 6. Antioxidant capacity (evaluated by DPPH and ABTS techniques) of apple starch films without ellagic acid (FILM-Control) and with ellagic acid (EA) added to $0.02 \%$ (FILM-EA0.02\%), 0.05\% (FILM-EA0.05\%) and 0.1\% (FILM-EA0.1\%). 


\section{Conclusions}

The mechanical properties of the films were affected depending on the concentration of EA, which was beneficial, because depending on the potential applications could adapt the mechanical properties. Incorporating EA promoted increases in opacity. This indicated that the films could be efficient in preventing the passage of UV light. The results of this study suggest that films based on apple starch added with ellagic acid (a nutraceutical agent with powerful antioxidant action) can be used for the development of active food packaging. Finally, it is necessary to explore strategies that increase the solubility of ellagic acid in the filmogenic solution and improve its incorporation in thermoplastic starch.

Author Contributions: Investigation and writing-original draft, J.M.T-G.; Methodology, J.d.J.O.-P., C.R.-V., G.I.O.O, M.A.A.-G. and D.L.-G.; Project administration, P.B.Z.-F.; Validation, H.Y.L.-D.1.P.; Visualization, F.H.-C.; Writing-original draft, M.E.-D. and M.H.-G.; Writing-review \& editing, R.B.-J. and J.J.B.-F.

Funding: This study is supported by CONACYT-Mexico and the Research Center for Food and Development (CIAD, A.C.).

Acknowledgments: The first author, J.M. Tirado-Gallegos thanks the National Council of Science and Technology (CONACYT) of Mexico for the scholarship granted to carry out doctoral studies at the "Centro de Investigación en Alimentación y Desarrollo (CIAD), A.C., Unidad Cuauhtémoc." The authors thank Emilio Ochoa Reyes for their technical assistance. This study is the product of the Research Group in Carbohydrates, Packaging and Functional Foods (CEAF) of CIAD-Cuauhtemoc, Chihuahua, Mexico led by Paul Baruk Zamudio-Flores.

Conflicts of Interest: The authors declare no conflict of interest.

\section{References}

1. Piñeros-Hernandez, D.; Medina-Jaramillo, C.; López-Córdoba, A.; Goyanes, S. Edible cassava starch films carrying rosemary antioxidant extracts for potential use as active food packaging. Food Hydrocoll. 2017, 63, 488-495. [CrossRef]

2. Reis, L.C.B.; de Souza, C.O.; da Silva, J.B.A.; Martins, A.C.; Nunes, I.L.; Druzian, J.I. Active biocomposites of cassava starch: The effect of yerba mate extract and mango pulp as antioxidant additives on the properties and the stability of a packaged product. Food Bioprod. Process. 2015, 94, 382-391. [CrossRef]

3. Oniszczuk, T.; Wójtowicz, A.; Moácicki, L.; Mitrus, M.; Kupryaniuk, K.; Kusz, A.; Bartnik, G. Effect of natural fibres on the mechanical properties of thermoplastic starch. Int. Agrophys. 2016, 30, 211-218. [CrossRef]

4. Jiménez, A.; Fabra, M.J.; Talens, P.; Chiralt, A. Edible and biodegradable starch films: A review. Food Bioprocess Technol. 2012, 5, 2058-2076. [CrossRef]

5. López, O.V.; Castillo, L.A.; García, M.A.; Villar, M.A.; Barbosa, S.E. Food packaging bags based on thermoplastic corn starch reinforced with talc nanoparticles. Food Hydrocoll. 2015, 43, 18-24. [CrossRef]

6. Ashwar, B.A.; Shah, A.; Gani, A.; Shah, U.; Gani, A.; Wani, I.A.; Wani, S.M.; Masoodi, F.A. Rice starch active packaging films loaded with antioxidants-development and characterization. Starch Stärke 2015, 67, 294-302. [CrossRef]

7. Zamudio-Flores, P.B.; Bello-Pérez, L.A. Elaboración y caracterización de películas de glicoproteínas obtenidas mediante reacción de Maillard utilizando almidón acetilado y aislado proteico de suero lácteo. Rev. Mex. Ing. Quim. 2013, 12, 401-413. (In Spanish)

8. Sapper, M.; Chiralt, A. Starch-Based Coatings for Preservation of Fruits and Vegetables. Coatings 2018, 8, 152. [CrossRef]

9. Yan, Q.; Hou, H.; Guo, P.; Dong, H. Effects of extrusion and glycerol content on properties of oxidized and acetylated corn starch-based films. Carbohydr. Polym. 2012, 87, 707-712. [CrossRef]

10. Chandra mohan, C.; Rakhavan, K.R.; Sudharsan, K.; Radha krishnan, K.; Babuskin, S.; Sukumar, M. Design and characterization of spice fused tamarind starch edible packaging films. LWT Food Sci. Technol. 2016, 68, 642-652. [CrossRef]

11. Famá, L.; Flores, S.K.; Gerschenson, L.; Goyanes, S. Physical characterization of cassava starch biofilms with special reference to dynamic mechanical properties at low temperatures. Carbohydr. Polym. 2006, 66, 8-15. [CrossRef] 
12. Mali, S.; Grossmann, M.V.E.; García, M.A.; Martino, M.N.; Zaritzky, N.E. Barrier, mechanical and optical properties of plasticized yam starch films. Carbohydr. Polym. 2004, 56, 129-135. [CrossRef]

13. Sanyang, M.L.; Sapuan, S.M.; Jawaid, M.; Ishak, M.R.; Sahari, J. Effect of plasticizer type and concentration on tensile, thermal and barrier properties of biodegradable films based on sugar palm (Arenga pinnata) starch. Polymers 2015, 7, 1106-1124. [CrossRef]

14. Sartori, T.; Menegalli, F.C. Development and characterization of unripe banana starch films incorporated with solid lipid microparticles containing ascorbic acid. Food Hydrocoll. 2016, 55, 210-219. [CrossRef]

15. Zamudio-Flores, P.B.; Vargas-Torres, A.; Pérez-González, J.; Bosquez-Molina, E.; Bello-Pérez, L.A. Films prepared with oxidized banana starch: Mechanical and barrier properties. Starch Stärke 2006, 58, 274-282. [CrossRef]

16. Daudt, R.M.; Avena-Bustillos, R.J.; Williams, T.; Wood, D.F.; Külkamp-Guerreiro, I.C.; Marczak, L.D.F.; McHugh, T.H. Comparative study on properties of edible films based on pinhão (Araucaria angustifolia) starch and flour. Food Hydrocoll. 2016, 60, 279-287. [CrossRef]

17. Tirado-Gallegos, J.M.; Zamudio-Flores, P.B.; Ornelas-Paz, J.d.J.; Rios-Velasco, C.; Acosta-Muñiz, C.H.; Gutiérrez-Meraz, F.; Islas-Hernández, J.J.; Salgado-Delgado, R. Efecto del método de aislamiento y el estado de madurez en las propiedades fisicoquímicas, estructurales y reológicas de almidón de manzana. Rev. Mex. Ing. Quim. 2016, 15, 391-408. (In Spanish)

18. Stevenson, D.G.; Domoto, P.A.; Jane, J.-L. Structures and functional properties of apple (Malus domestica Borkh) fruit starch. Carbohydr. Polym. 2006, 63, 432-441. [CrossRef]

19. Shi, Y.; Jiang, L.; Zhang, L.; Kang, R.; Yu, Z. Dynamic changes in proteins during apple (Malus x domestica) fruit ripening and storage. Hortic. Res. 2014, 1, 6. [CrossRef] [PubMed]

20. Berlanga Reyes, D.I.; Romo Chacón, A.; Martínez Campos, Á.R.; Guerrero Prieto, V.M. Apple fruit chemical thinning in Chihuahua, Mexico. Rev. Fitotec. Mex. 2008, 31, 243-250.

21. Rascón-Chu, A.; Martínez-López, A.-L.; Carvajal-Millán, E.; Martínez-Robinson, K.G.; Campa-Mada, A.C. Gelificación iónica de pectina de bajo grado de esterificación extraída de manzanas inmaduras de raleo. Rev. Fitotec. Mex. 2016, 39, 17-24. (In Spanish)

22. Berlanga-Reyes, D.I.; Rios-Velasco, C.; Romo-Chacón, A.; Guerrero-Prieto, V.M. Raleo químico de flores de manzano (Malus x domestica Borkh.) 'Golden Delicious’ y ‘RedChief Delicious'. Tecnociencia Chihuah. 2012, 6, 147-157. (In Spanish)

23. Romero, V.; Borneo, R.; Passalacqua, N.; Aguirre, A. Biodegradable films obtained from triticale ( $x$ Triticosecale Wittmack) flour activated with natamycin for cheese packaging. J. Food Packag. Shelf Life 2016, 10, 54-59. [CrossRef]

24. Cano, A.; Cháfer, M.; Chiralt, A.; González-Martínez, C. Development and characterization of active films based on starch-PVA, containing silver nanoparticles. J. Food Packag. Shelf Life 2016, 10, 16-24. [CrossRef]

25. Shah, U.; Gani, A.; Ashwar, B.A.; Shah, A.; Ahmad, M.; Gani, A.; Wani, I.A.; Masoodi, F.A.; Yildiz, F. A review of the recent advances in starch as active and nanocomposite packaging films. Cogent Food Agric. 2015, 1, 1115640. [CrossRef]

26. Mehyar, G.F.; Han, J.H. Physical and mechanical properties of high-amylose rice and pea starch films as affected by relative humidity and plasticizer. J. Food Sci. 2004, 69, E449-E454. [CrossRef]

27. De Araújo, G.K.P.; de Souza, S.J.; da Silva, M.V.; Yamashita, F.; Gonçalves, O.H.; Leimann, F.V.; Shirai, M.A. Physical, antimicrobial and antioxidant properties of starch-based film containing ethanolic propolis extract. Int. J. Food Sci. Technol. 2015, 50, 2080-2087. [CrossRef]

28. Corrales, M.; Han, J.H.; Tauscher, B. Antimicrobial properties of grape seed extracts and their effectiveness after incorporation into pea starch films. Int. J. Food Sci. Technol. 2009, 44, 425-433. [CrossRef]

29. Medina, J.C.; Gutiérrez, T.J.; Goyanes, S.; Bernal, C.; Famá, L. Biodegradability and plasticizing effect of yerba mate extract on cassava starch edible films. Carbohydr. Polym. 2016, 151, 150-159. [CrossRef] [PubMed]

30. Kim, S.; Liu, Y.; Gaber, M.W.; Bumgardner, J.D.; Haggard, W.O.; Yang, Y. Development of chitosan-ellagic acid films as a local drug delivery system to induce apoptotic death of human melanoma cells. J. Biomed. Mater. Res. Part B Appl. Biomater. 2009, 90, 145-155. [CrossRef] [PubMed]

31. Seeram, N.P.; Adams, L.S.; Henning, S.M.; Niu, Y.; Zhang, Y.; Nair, M.G.; Heber, D. In vitro antiproliferative, apoptotic and antioxidant activities of punicalagin, ellagic acid and a total pomegranate tannin extract are enhanced in combination with other polyphenols as found in pomegranate juice. J. Nutr. Biochem. 2005, 16, 360-367. [CrossRef] [PubMed] 
32. Baek, B.; Lee, S.H.; Kim, K.; Lim, H.-W.; Lim, C.-J. Ellagic acid plays a protective role against UV-B-induced oxidative stress by up-regulating antioxidant components in human dermal fibroblasts. Korean J. Physiol. Pharmacol. 2016, 20, 269-277. [CrossRef] [PubMed]

33. Kilic, I.; Yeşiloğlu, Y.; Bayrak, Y. Spectroscopic studies on the antioxidant activity of ellagic acid. Spectrochim. Acta Part A Mol. Biomol. Spectrosc. 2014, 130, 447-452. [CrossRef] [PubMed]

34. Bala, I.; Bhardwaj, V.; Hariharan, S.; Kumar, M.R. Analytical methods for assay of ellagic acid and its solubility studies. J. Pharm. Biomed. Anal. 2006, 40, 206-210. [CrossRef] [PubMed]

35. Saucedo-Pompa, S.; Jasso-Cantu, D.; Ventura-Sobrevilla, J.; SÁEnz-Galindo, A.; RodrÍGuez-Herrera, R.; Aguilar, C.N. Effect of candelilla wax with natural antioxidants on the shelf life quality of fresh-cut fruits. J. Food Qual. 2007, 30, 823-836. [CrossRef]

36. Saucedo-Pompa, S.; Rojas-Molina, R.; Aguilera-Carbó, A.F.; Saenz-Galindo, A.; Garza, H.d.L.; Jasso-Cantú, D.; Aguilar, C.N. Edible film based on candelilla wax to improve the shelf life and quality of avocado. Food Res. Int. 2009, 42, 511-515. [CrossRef]

37. Mali, S.; Grossmann, M.V.E.; Garcia, M.A.; Martino, M.N.; Zaritzky, N.E. Microstructural characterization of yam starch films. Carbohydr. Polym. 2002, 50, 379-386. [CrossRef]

38. Zamudio-Flores, P.B.; Ochoa-Reyes, E.; Ornelas-Paz, J.D.J.; Tirado-Gallegos, J.M.; Bello-Pérez, L.A.; Rubio-Ríos, A.; Cárdenas-Felix, R.G. Caracterización fisicoquímica, mecánica y estructural de películas de almidones oxidados de avena y plátano adicionadas con betalaínas. Agrociencia 2015, 49, 483-498. (In Spanish)

39. Luchese, C.L.; Garrido, T.; Spada, J.C.; Tessaro, I.C.; de la Caba, K. Development and characterization of cassava starch films incorporated with blueberry pomace. Int. J. Biol. Macromol. 2018, 106, 834-839. [CrossRef] [PubMed]

40. López-Mata, M.A.; Ruiz-Cruz, S.; Silva-Beltrán, N.P.; Ornelas-Paz, J.D.J.; Zamudio-Flores, P.B.; Burruel-Ibarra, S.E. Physicochemical, antimicrobial and antioxidant properties of chitosan films incorporated with carvacrol. Molecules 2013, 18, 13735-13753. [CrossRef] [PubMed]

41. Official Methods of Analysis, 16th ed.; Association of Official Analytical Chemist: Washington, DC, USA, 1995.

42. Colla, E.; do Amaral Sobral, P.J.; Menegalli, F.C. Amaranthus cruentus flour edible films: Influence of stearic acid addition, plasticizer concentration and emulsion stirring speed on water vapor permeability and mechanical properties. J. Agric. Food Chem. 2006, 54, 6645-6653. [CrossRef] [PubMed]

43. ASTM-E-96-80 Standard Methods of Test for Water Vapor Transmission of Materials in Sheet Form; ASTM International: West Conshohocken, PA, USA, 2016.

44. Mali, S.; Sakanaka, L.S.; Yamashita, F.; Grossmann, M.V.E. Water sorption and mechanical properties of cassava starch films and their relation to plasticizing effect. Carbohydr. Polym. 2005, 60, 283-289. [CrossRef]

45. ASTM-882-95a Standard Test Methods for Tensile Properties of Thin Plastic Sheeting; ASTM International: West Conshohocken, PA, USA, 1995.

46. Teodoro, A.P.; Mali, S.; Romero, N.; de Carvalho, G.M. Cassava starch films containing acetylated starch nanoparticles as reinforcement: Physical and mechanical characterization. Carbohydr. Polym. 2015, 126, 9-16. [CrossRef] [PubMed]

47. Brand-Williams, W.; Cuvelier, M.E.; Berset, C. Use of a free radical method to evaluate antioxidant activity. LWT Food Sci. Technol. 1995, 28, 25-30. [CrossRef]

48. Re, R.; Pellegrini, N.; Proteggente, A.; Pannala, A.; Yang, M.; Rice-Evans, C. Antioxidant activity applying an improved ABTS radical cation decolorization assay. Free Radic. Biol. Med. 1999, 26, 1231-1237. [CrossRef]

49. Nouri, L.; Mohammadi, N.A. Antibacterial, mechanical and barrier properties of sago starch film incorporated with betel leaves extract. Int. J. Biol. Macromol. 2014, 66, 254-259. [CrossRef] [PubMed]

50. Medina-Jaramillo, C.; Ochoa-Yepes, O.; Bernal, C.; Famá, L. Active and smart biodegradable packaging based on starch and natural extracts. 2017, 176, 187-194. [CrossRef] [PubMed]

51. Shiku, Y.; HamaguchI, P.Y.; Tanaka, M. Effect of $\mathrm{pH}$ on the preparation of edible films based on fish myofibrillar proteins. Fish. Sci. 2003, 69, 1026-1032. [CrossRef]

52. García, M.A.; Martino, M.N.; Zaritzky, N.E. Lipid addition to improve barrier properties of edible starch-based films and coatings. J. Food Sci. 2000, 65, 941-944. [CrossRef]

53. Versino, F.; García, M.A. Cassava (Manihot esculenta) starch films reinforced with natural fibrous filler. Ind. Crops Prod. 2014, 58, 305-314. [CrossRef]

54. Arulmozhi, V.; Pandian, K.; Mirunalini, S. Ellagic acid encapsulated chitosan nanoparticles for drug delivery system in human oral cancer cell line (KB). Colloids Surf. B Biointerface 2013, 110, 313-320. [CrossRef] [PubMed] 
55. Bikiaris, D.; Panayiotou, C. LDPE/starch blends compatibilized with PE-g-MA copolymers. J. Appl. Polym. Sci. 1998, 70, 1503-1521. [CrossRef]

56. Wu, Y.-P.; Ji, M.-Q.; Qi, Q.; Wang, Y.-Q.; Zhang, L.-Q. Preparation, structure and properties of starch/rubber composites prepared by co-coagulating rubber latex and starch paste. Macromol. Rapid. Commun. 2004, 25, 565-570. [CrossRef]

57. Chai, Y.; Wang, M.; Zhang, G. Interaction between amylose and tea polyphenols modulates the postprandial glycemic response to high-amylose maize starch. J. Agric. Food Chem. 2013, 61, 8608-8615. [CrossRef] [PubMed]

58. Pelissari, F.M.; Andrade-Mahecha, M.M.; do Amaral Sobral, P.J.; Menegalli, F.C. Isolation and characterization of the flour and starch of plantain bananas (Musa paradisiaca). Starch Stärke 2012, 64, 382-391. [CrossRef]

59. Mano, J.F.; Koniarova, D.; Reis, R.L. Thermal properties of thermoplastic starch/synthetic polymer blends with potential biomedical applicability. J. Mater. Sci. Mater. Med. 2003, 14, 127-135. [CrossRef] [PubMed]

60. Das, D.; Jha, S.; Kumar, K.J. Isolation and release characteristics of starch from the rhizome of Indian Palo. Int. J. Biol. Macromol. 2015, 72, 341-346. [CrossRef] [PubMed]

61. Hussein, M.Z.; Al Ali, S.H.; Zainal, Z.; Hakim, M.N. Development of antiproliferative nanohybrid compound with controlled release property using ellagic acid as the active agent. Int. J. Nanomed. 2011, 6, 1373-1383. [CrossRef] [PubMed]

62. Li, X.; Qiu, C.; Ji, N.; Sun, C.; Xiong, L.; Sun, Q. Mechanical, barrier and morphological properties of starch nanocrystals-reinforced pea starch films. Carbohydr. Polym. 2015, 121, 155-162. [CrossRef] [PubMed]

63. Perazzo, K.K.N.C.L.; de Vasconcelos Conceição, A.C.; dos Santos, J.C.P.; de Jesus Assis, D.; Souza, C.O.; Druzian, J.I. Properties and antioxidant action of actives cassava starch films incorporated with green tea and palm oil extracts. PLoS ONE 2014, 9, e105199. [CrossRef] [PubMed]

(C) 2018 by the authors. Licensee MDPI, Basel, Switzerland. This article is an open access article distributed under the terms and conditions of the Creative Commons Attribution (CC BY) license (http:/ / creativecommons.org/licenses/by/4.0/). 